\title{
Evaluating the Sawability of Rocks by Chain-Saw Machines using the PROMETHEE Technique
}

Rudarsko-geološko-naftni zbornik

(The Mining-Geology-Petroleum Engineering Bulletin) UDC: 622.2

DOI: 10.17794/rgn.2021.1.3

Original scientific paper

\author{
Reza Mikaeil'; Akbar Esmaeilzadeh'; Sara Aghaei'; Sina Shaffiee Haghshenas²; \\ Amir Jafarpour ${ }^{3}$; Javad Mohammadi'; Mohammad Ataei ${ }^{4}$; \\ ${ }^{1}$ Department of Mining and Engineering, Faculty of Environment, Urmia University of Technology, Urmia, Iran \\ ${ }^{2}$ Department of Civil Engineering, University of Calabria, Via Bucci, 87036 Rende, Italy, http://orcid.org/0000-0003-2859-3920 \\ ${ }^{3}$ Department of Mining and Metallurgical Engineering, Yazd University \\ ${ }^{4}$ School of Mining, Petroleum \& Geophysics Engineering, Shahrood University of Technology, Shahrood, Iran
}

\begin{abstract}
One of the most significant factors in the estimation of dimension stone quarry cost is the production rate of rock cutting machines. Evaluating the production rate of chain-saw machines is a very significant and practical issue. In this research, it has been attempted to evaluate and select the suitable working-face for a quarry by examining the maximum production rate in the Dehbid and Shayan marble quarries. For this purpose, field studies were carried out which included measuring operational characteristics of the chain-saw cutting machine, the production rate and sampling for laboratory tests from seven active case studies. Subsequently, the physical and mechanical properties of rocks including: Uniaxial Compressive Strength (UCS), Brazilian Tensile Strength (BTS), Los Angeles abrasion, quartz content, water absorption percentage, porosity, Schmidt hardness and grain size for all sample measurements were studied after transferring the samples to a rock-mechanics laboratory. Finally, the sawability of the quarried working-faces was evaluated using the PROMETHEE multi-criteria decision-making (MCDM) model according to the physical and mechanical properties. The results of the study indicated that the number 1 and 5 working-faces from the Dehbid and Shayan quarries are the most suitable working-faces in terms of production rate with the maximum recorded production values $\left(4.95\right.$ and $\left.3.1 \mathrm{~m}^{2} / \mathrm{h}\right)$, and with net flow rates $(2.67$ and -0.36$)$ respectively.
\end{abstract}

\section{Keywords:}

Dimension stone quarries; Chain-saw machine; Production rate; PROMETHEE

\section{Introduction}

The production rate of stone cutting machines plays a key role in dimension stone quarries when considering the final costs of extracting a stone block. Numerous methods are used to extract dimension stones in quarries. Currently, the diamond cutting-wire method is used in most quarries for extraction (Korman et al. 2016; Mikaeil et al., 2018a). Using diamond cutting wire has disadvantages such as high risk of hazards and reduced safety compared to other methods. The chainsaw machine cutting method is a suitable solution for extracting dimension stones that has advantages such as: increased safety, the quality of the extracted stone block and ease of work. Given the advantages of a chainsaw cutting machine, it is predicted that the use of this machine will completely replace the use of other methods for cutting dimension stones in the next few years. The production rate in the chainsaw machine extraction method depends on various factors including the physical and mechanical characteristics of the stone, structural characteristics of

Corresponding author: Sina Shaffiee Haghshenas

s.shaffiee@yahoo.com the machine and operational parameters of the machine. Therefore, to assess the production rate, access to sufficient information about the type of the mineral, physical and mechanical characteristics of the intended stone and controllable parameters, including the characteristics of the chainsaw machine and operational parameters are key factors. As of yet, many studies have been conducted on the effect of stone properties on the performance of cutting machines, an important part of which is presented in Table 1.

It is certain that in the coming years, the use of chainsaws will be a complete alternative to the diamond wire cutting method. Also, it should be noted that many studies on the use of chainsaws have been conducted by researchers in recent years, which shows the efficiency of the chainsaw cutting method.

It is evident that many studies performed on stone cutting have suggested diamond cutting wire and cutting discs, and in this regard, a lot of research (unlike the necessary research on chainsaw cutting machines) has been carried out. Today, however, stone cutting methods with the use of chainsaw machines is on the rise. Some of the important studies done in this field could be de- 
Table 1: Studies on the performance of stone cutting machines

\begin{tabular}{|c|c|c|c|c|c|c|c|c|c|c|c|c|c|c|c|}
\hline \multirow{2}{*}{ Researchers } & \multirow{2}{*}{ Year } & \multicolumn{2}{|c|}{ Saw type } & \multicolumn{12}{|c|}{ Physical and mechanical properties } \\
\hline & & W & $\mathrm{C}$ & UCS & BTS & YM & IS & SS & BS & $\mathrm{H}$ & A & $\mathrm{D}$ & Gs & Qc & Ws \\
\hline Burgess and Birle & 1978 & & $\bullet$ & & & & & & & & & & $\bullet$ & $\bullet$ & \\
\hline Wright and Cassapi & 1985 & & $\bullet$ & $\bullet$ & $\bullet$ & & & & & $\bullet$ & $\bullet$ & & & $\bullet$ & \\
\hline Birle and Ratterman & 1986 & & $\bullet$ & & & & & & & $\bullet$ & & & & & \\
\hline Jennings and Wright & 1989 & & $\bullet$ & $\bullet$ & $\bullet$ & & & & & $\bullet$ & & & & $\bullet$ & \\
\hline Clausen et al. & 1996 & & - & & & & & & & & & & $\bullet$ & - & \\
\hline Ciccu et al. & 1999 & $\bullet$ & & & & $\bullet$ & & & & $\bullet$ & & & & & $\bullet$ \\
\hline Agus et al. & 2003 & $\bullet$ & & & & & & & & $\bullet$ & & & $\bullet$ & $\bullet$ & \\
\hline Wei et al. & 2003 & & $\bullet$ & $\bullet$ & & & & & & $\bullet$ & $\bullet$ & & & $\bullet$ & \\
\hline Eyuboglu et al. & 2003 & & $\bullet$ & $\bullet$ & $\bullet$ & $\bullet$ & & & & $\bullet$ & & & & & \\
\hline Ersoy and Atici & 2004 & & $\bullet$ & $\bullet$ & $\bullet$ & $\bullet$ & $\bullet$ & $\bullet$ & $\bullet$ & $\bullet$ & $\bullet$ & $\bullet$ & $\bullet$ & $\bullet$ & \\
\hline Kahraman et al. & 2004 & & $\bullet$ & $\bullet$ & $\bullet$ & & $\bullet$ & & & $\bullet$ & $\bullet$ & & & & \\
\hline Gunaydin et al. & 2004 & & $\bullet$ & $\bullet$ & $\bullet$ & & $\bullet$ & & & & & & & & \\
\hline Ozcelik et al. & 2004 & $\bullet$ & & $\bullet$ & $\bullet$ & $\bullet$ & & & & $\bullet$ & & $\bullet$ & & $\bullet$ & \\
\hline Buyuksagis and Goktan & 2005 & & $\bullet$ & $\bullet$ & $\bullet$ & & & & & $\bullet$ & $\bullet$ & & & $\bullet$ & \\
\hline Ersoy et al. & 2005 & & $\bullet$ & $\bullet$ & $\bullet$ & $\bullet$ & $\bullet$ & $\bullet$ & $\bullet$ & & $\bullet$ & $\bullet$ & & $\bullet$ & \\
\hline Delgado et al. & 2005 & & $\bullet$ & & & & & & & $\bullet$ & & & & $\bullet$ & \\
\hline Kahraman et al. & 2005 & & $\bullet$ & & & & & $\bullet$ & & & & & & $\bullet$ & \\
\hline Cai et al. & 2007 & $\bullet$ & & $\bullet$ & & $\bullet$ & $\bullet$ & & $\bullet$ & & & $\bullet$ & & & \\
\hline Fener et al. & 2007 & & $\bullet$ & $\bullet$ & $\bullet$ & & $\bullet$ & & & $\bullet$ & $\bullet$ & & & & \\
\hline Kahraman et al. & 2007 & & $\bullet$ & $\bullet$ & $\bullet$ & & & & & & & $\bullet$ & & $\bullet$ & \\
\hline Ozcelik & 2007 & $\bullet$ & & $\bullet$ & $\bullet$ & & & & & $\bullet$ & & & & $\bullet$ & \\
\hline Tutmez et al. & 2007 & & $\bullet$ & - & $\bullet$ & & $\bullet$ & & & - & $\bullet$ & & & & \\
\hline Buyuksagis & 2007 & & $\bullet$ & $\bullet$ & $\bullet$ & & & & $\bullet$ & - & $\bullet$ & $\bullet$ & & - & \\
\hline Mikaeil et al. & 2008 & $\bullet$ & & $\bullet$ & & & & & & & & & & $\bullet$ & \\
\hline Kahraman and Gunaydin & 2008 & & $\bullet$ & & & & & & & $\bullet$ & & $\bullet$ & & & \\
\hline Mikaeil et al. & 2011 & & $\bullet$ & $\bullet$ & $\bullet$ & & & & & & & & & & \\
\hline Ataei et al. & 2012 & & $\bullet$ & $\bullet$ & $\bullet$ & & & & & $\bullet$ & $\bullet$ & & & & \\
\hline Ataei et al. & 2012 & $\bullet$ & & $\bullet$ & $\bullet$ & & & & & $\bullet$ & $\bullet$ & & $\bullet$ & $\bullet$ & \\
\hline Yurdakul and Akdas & 2012 & & $\bullet$ & $\bullet$ & $\bullet$ & & & & $\bullet$ & $\bullet$ & $\bullet$ & $\bullet$ & & & \\
\hline Ghaysari et al. & 2012 & $\bullet$ & & & & & & & & & & & $\bullet$ & & \\
\hline Mikaeil et al. & 2013 & & $\bullet$ & $\bullet$ & $\bullet$ & $\bullet$ & & & & $\bullet$ & $\bullet$ & & $\bullet$ & $\bullet$ & \\
\hline Sadegheslam et al. & 2013 & $\bullet$ & & $\bullet$ & & $\bullet$ & & & & & $\bullet$ & & & $\bullet$ & \\
\hline Careddu and Cai & 2014 & $\bullet$ & $\bullet$ & & & & & & & & & & & & \\
\hline Careddu and Lanceni & 2015 & $\bullet$ & $\bullet$ & & & & & & & & & & & & \\
\hline Tumac & 2015 & & $\bullet$ & & & & & & & $\bullet$ & $\bullet$ & & & & \\
\hline Mikaeil et al. & 2016 & & $\bullet$ & $\bullet$ & $\bullet$ & $\bullet$ & & & & $\bullet$ & $\bullet$ & & $\bullet$ & $\bullet$ & \\
\hline Aryafar and Mikaeil & 2016 & & $\bullet$ & $\bullet$ & $\bullet$ & $\bullet$ & & & & $\bullet$ & $\bullet$ & & $\bullet$ & $\bullet$ & \\
\hline Tumac & 2016 & & - & - & $\bullet$ & & & & & & $\bullet$ & - & & & \\
\hline Almasi et al. & $2017 \mathbf{a}$ & $\bullet$ & & $\bullet$ & $\bullet$ & $\bullet$ & & & & - & $\bullet$ & & $\bullet$ & - & \\
\hline Almasi et al. & $2017 b$ & $\bullet$ & & $\bullet$ & $\bullet$ & $\bullet$ & & & & - & $\bullet$ & & $\bullet$ & $\bullet$ & \\
\hline Almasi et al. & $2017 \mathrm{c}$ & $\bullet$ & & $\bullet$ & $\bullet$ & $\bullet$ & & & & $\bullet$ & $\bullet$ & & $\bullet$ & $\bullet$ & \\
\hline Kamran et al. & 2017 & $\bullet$ & & $\bullet$ & $\bullet$ & $\bullet$ & & & & $\bullet$ & $\bullet$ & & $\bullet$ & $\bullet$ & \\
\hline Akhyani et al. & 2017 & & $\bullet$ & $\bullet$ & $\bullet$ & $\bullet$ & & & & $\bullet$ & $\bullet$ & & $\bullet$ & $\bullet$ & \\
\hline Mikaeil et al. & 2017 & $\bullet$ & & $\bullet$ & $\bullet$ & $\bullet$ & & & & $\bullet$ & $\bullet$ & & $\bullet$ & $\bullet$ & \\
\hline Yilmazkaya et al. & 2018 & $\bullet$ & & $\bullet$ & & $\bullet$ & $\bullet$ & $\bullet$ & $\bullet$ & & $\bullet$ & & $\bullet$ & $\bullet$ & \\
\hline Tumac and Shaterpour & 2018 & & $\bullet$ & & & $\bullet$ & $\bullet$ & $\bullet$ & & & & & $\bullet$ & $\bullet$ & \\
\hline Aryafar et al. & $2018 \mathrm{a}$ & & $\bullet$ & $\bullet$ & $\bullet$ & $\bullet$ & & & & $\bullet$ & $\bullet$ & & $\bullet$ & $\bullet$ & \\
\hline Aryafar et al. & $2018 b$ & & $\bullet$ & $\bullet$ & $\bullet$ & $\bullet$ & & & & $\bullet$ & $\bullet$ & & $\bullet$ & $\bullet$ & \\
\hline Akhyani et al. & 2018 & & $\bullet$ & $\bullet$ & $\bullet$ & & & & & & & & & & \\
\hline Mikaeil et al. & $2018 b$ & & $\bullet$ & $\bullet$ & $\bullet$ & $\bullet$ & & & & $\bullet$ & $\bullet$ & & $\bullet$ & $\bullet$ & \\
\hline Mikaeil et al. & $2018 c$ & & $\bullet$ & $\bullet$ & $\bullet$ & $\bullet$ & & & & $\bullet$ & $\bullet$ & & $\bullet$ & $\bullet$ & \\
\hline Careddu et al. & 2018 & $\bullet$ & & $\bullet$ & & & & & $\bullet$ & & $\bullet$ & $\bullet$ & & & \\
\hline Careddu et al. & 2019 & $\bullet$ & & $\bullet$ & & & & & $\bullet$ & & $\bullet$ & $\bullet$ & & & \\
\hline Akhyani et al. & 2019 & & $\bullet$ & $\bullet$ & $\bullet$ & $\bullet$ & & & & $\bullet$ & $\bullet$ & & $\bullet$ & $\bullet$ & \\
\hline Mohammadi et al. & 2019 & & $\bullet$ & $\bullet$ & $\bullet$ & $\bullet$ & & & & $\bullet$ & $\bullet$ & & $\bullet$ & $\bullet$ & \\
\hline Dormishi et al. & 2019a & & $\bullet$ & $\bullet$ & $\bullet$ & $\bullet$ & & & & $\bullet$ & $\bullet$ & & $\bullet$ & $\bullet$ & \\
\hline Dormishi et al. & $2019 b$ & & $\bullet$ & - & $\bullet$ & $\bullet$ & & & & $\bullet$ & $\bullet$ & & $\bullet$ & $\bullet$ & \\
\hline Mikaeil et al. & 2019a & & $\bullet$ & - & $\bullet$ & $\bullet$ & & & & $\bullet$ & $\bullet$ & & $\bullet$ & $\bullet$ & \\
\hline Haghshenas et al. & 2019 & & $\bullet$ & $\bullet$ & $\bullet$ & $\bullet$ & & & & $\bullet$ & $\bullet$ & & $\bullet$ & $\bullet$ & \\
\hline Hosseini et al. & 2019 & & $\bullet$ & $\bullet$ & $\bullet$ & $\bullet$ & & & & $\bullet$ & $\bullet$ & & $\bullet$ & $\bullet$ & \\
\hline Hosseini et al. & $2020 a$ & & $\bullet$ & $\bullet$ & $\bullet$ & $\bullet$ & & & & $\bullet$ & $\bullet$ & & $\bullet$ & $\bullet$ & \\
\hline Hosseini et al. & $2020 \mathrm{~b}$ & & $\bullet$ & $\bullet$ & $\bullet$ & $\bullet$ & & & & $\bullet$ & $\bullet$ & & $\bullet$ & $\bullet$ & \\
\hline
\end{tabular}


scribed as follows. Sariisik and Sariisik (2010) analyzed the productivity of chainsaw cutting machines in the production of stone blocks in the Kalkik and Kokabas travertine quarries located in Turkey. In this study, the researchers described the steps of both methods used for extraction. They concluded that the effective parameters in the chainsaw machine extraction method, in the production of stone blocks and ultimately the productivity of the mine, included the geological and geotechnical conditions of the mine, the characteristics of the chainsaw machine used and the operational parameters (Sariisik and Sariisik 2010).

Copur et al. (2006) studied the cutting performance of chainsaw machines in a travertine quarry in Basaranella, Turkey and on laboratory samples. In this research, the performance of the chainsaw machine depended on the geological characteristics of the mine (joint, dip and persistence of the stone layer), characteristics of the undisturbed stone sample (uniaxial compressive strength, Brazilian tensile strength and elasticity characteristics), mechanical parameters (torque capacities, power, throwing, blade length and cutting tool characteristics) as well as operating parameters (blade angle, chain rotation speed and cart speed). The researchers concluded that for travertine extraction, a combination of two methods of chainsaw machine and diamond wire cutting machine increased and improved the extraction performance by up to 20\% (Copur et al. 2006). In another study, Copur (2010) investigated and estimated the performance of a chainsaw cutting machine via linear cuts and conduct of experiments on stone blocks. The findings of experimental studies and field research suggested that the cutting operation of this machine can be simulated by linear cutting experiments, and the stated model can be selected as a useful and reliable tool for selecting, designing, predicting performance and optimizing the chainsaw cutting machine (Copur et al. 2010). In addition, Copur et al. (2011) conducted field and laboratory studies (linear cutting test) on dimension stones (two kinds of travertine and three kinds of marble) to predict the performance of chainsaw cutting machines. In this investigation, two field and laboratory models were employed as the baseline and the findings suggested that the type of chainsaw cutting machine should match with the rock characteristics in the mine; in the meantime, prior to choosing the machine model, mechanical and physical characteristics of the rock such as uniaxial compressive strength, Brazilian tensile strength, specific gravity, static and dynamic elasticity module, Poisson's ratio and porosity should be considered. The findings of this study showed that among the physical and mechanical characteristics, the two parameters of uniaxial compressive strength and Brazilian tensile strength are the most significant and effective parameters. This study was the first field model on the basis of chainsaw penetration index while the uniaxial compressive strength of the stone, chainsaw ma- chine weight and arm cutting depth were chosen as the main predicting parameters. Another model according to the results of linear cutting experiments and specific energy was chosen as the predicting parameter (Copur et al. 2011). Tumac et al. (2013) predicted the performance of chainsaw cutting machines using hardness parameters and other mechanical properties of the rock. In this study, six samples of dimension stones from six quarries in Turkey were investigated. The mechanical specifications of this study were: uniaxial compressive strength, Brazilian tensile strength, surcharge absorption index, Schmidt's hammer hardness index and scleroscope hardness index. The relationship between surface cutting rate and each of the stone mechanical parameters was then analyzed. The obtained results showed that by increasing uniaxial compressive strength, the surface shear rate decreased (Tumac et al. 2013). In yet another study, Tumac (2013) studied the performance estimate of a chainsaw machine using a hardness scale and the mechanical and physical properties of the stone. In this research, the scleroscope hardness index was used to determine the performance of chainsaw machines. The measured hardness values were achieved to be correlated with the physical and mechanical characteristics of rock and cutting parameters (normal force, cutting force and specific energy) resulting from linear cutting tests, without cutting and net cutting speed of the machine. Hekimoglu (2014) conducted his study on the effects of increasing the performance of chainsaw cutting machines on extracting dimension stones. In this study, in order to increase the performance of chainsaw cutting machines, the focus is on cutting rate sections and reducing the friction of cutting tools, which is achieved by reducing the original cutting tools and improving them, thus improving the performance of the chainsaw machine (Hekimoglu et al. 2014). Korman et al. (2015) simulated the process of chainsaw machine cutting by a linear cutting machine. Laboratory studies were performed on a fixed stone sample with cutting depths of 0.2 to $0.6 \mathrm{~mm}$. In this laboratory simulation, the main parameter was cutting energy. The results of this experiment indicated that the cutting energy was directly related to the cutting depth and inversely related to the sawing speed (Korman et al. 2015). Mohammadi et al. (2018) also performed their study on modeling and predicting the production rate of chainsaw cutting machines by way of intelligent neural networks. To this end, first the laboratory test parameters on calcium carbonate stone were investigated and the operating parameters of the machine, arm angle, saw speed and machine speed were taken into account. Some properties of the stone were studied such as uniaxial compressive strength, Los Angeles abrasion test and Schmidt hammer as input data. Given that in this research, the production rate by the chainsaw cutting machine was the output of the experiment, the findings of the performance indicators of the model showed that a very good prediction had been 


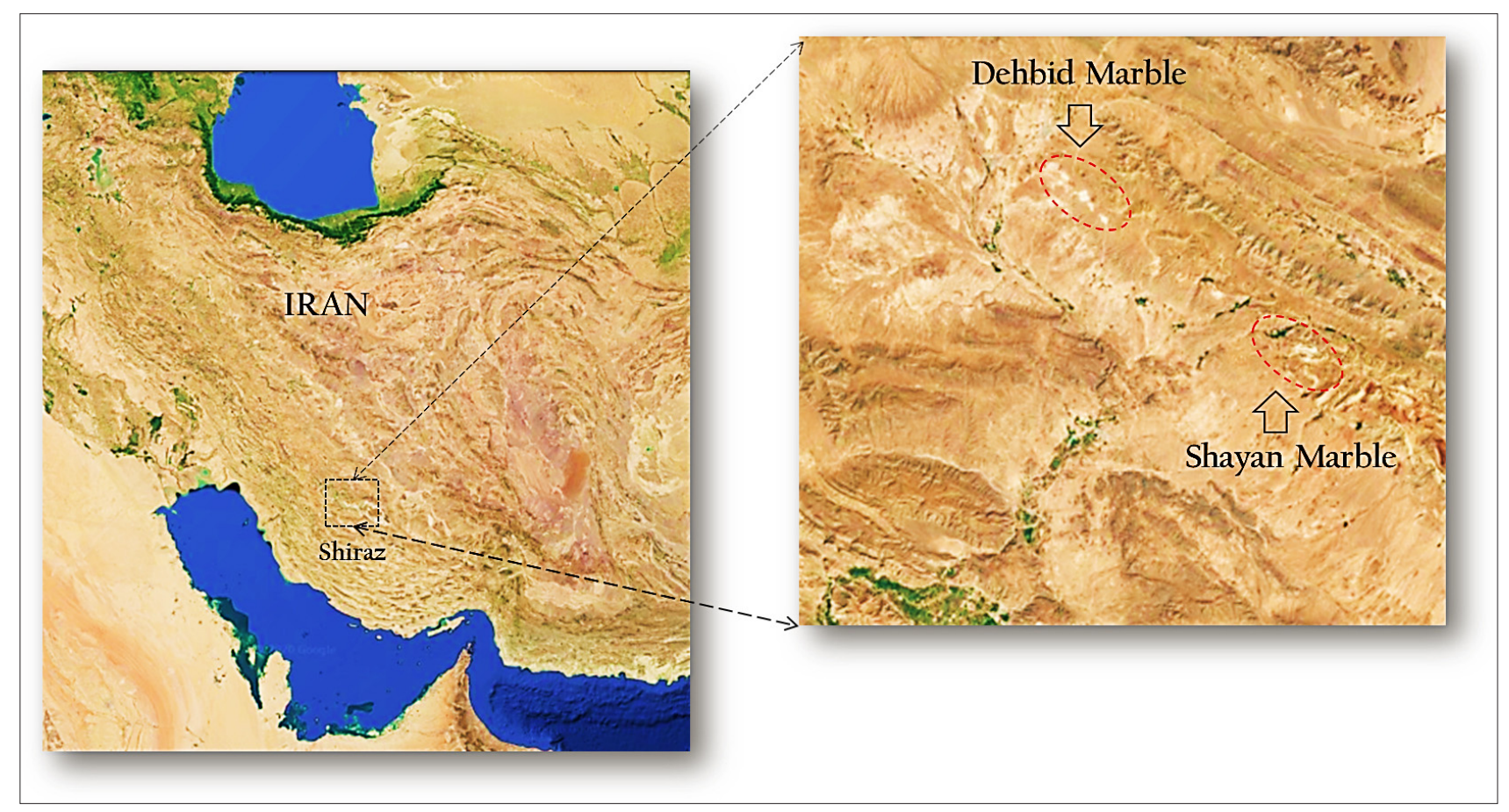

Figure 1: Geographical location of the Dehbid and Shayan quarries

made for measuring the production of the chainsaw machine using intelligent neural networks (Mohammadi et al. 2018).

Mohammadi et al. (2019) conducted another study with the aim of developing and predicting the production rate of a chainsaw cutting machine using RBF and GMDH intelligent neural networks. Finally, first some laboratory studies were carried out on 7 carbonate stone samples and the production rate of each experiment was measured. Operational characteristics of machines (arm angle, saw speed and machine speed) as well as three important physical and mechanical characteristics (uniaxial compressive strength, Los Angeles abrasion test and Schmidt hammer hardness) were taken into account as input data and the production rate was considered as output data. The obtained results suggested that the developed model can provide better results for forecasting the production rate of a chainsaw cutting machine (Mohammadi et al., 2019). Given the importance of the stone cutting method with the chainsaw cutting machine and in accordance with the fact that scant research has been done in this regard, in this research, it was attempted to rank the faces extracted by chainsaw machines in accordance with the production rate via the PROMETHEE multi-criterion decision-making method.

Since the ranking of the faces exacted in quarries can contribute to reduced costs and also the extraction time, two marble quarries in Dehbid and Shayan were chosen in this study for ranking. In the first step, stone samples were taken from faces extracted in the mentioned quarries. Then, field and laboratory studies were performed on the studied faces and samples to determine the production rate and physical and mechanical characteris- tics. In the next stage, the PROMETHEE decision method was employed to rank the faces. Seven faces were chosen as decision options with the physical and mechanical properties of the stone being selected as decision criteria and the criteria were scored by the simple weighting method. In the end, according to the input and output currents and the obtained net current, the faces were ranked by cutting-ability with a chainsaw cutting machine.

\section{Case studies}

To assess the performance of the chainsaw cutting machine on marble dimension stone quarries, field and laboratory studies respecting active faces in two marble quarries of Dehbid and Shayan in the Fars province were done by focusing on the subject of cutting capability (production rate evaluation). The Dehbid and Shayan marble quarries are located in the Fars province, northeast of Shiraz city, with an altitude of 2450 meters and 3200 meters above sea level, respectively, have a certain marble reserve of 19 million tons and 4 million tons, respectively, as they have employed 550 and 240 people and produce an annual rate of 300 thousand tons and 100 thousand tons. Figure 1 shows the geographical location of the quarries in question and the distance between the two quarries. The Dehbid and Shayan quarries are located $127 \mathrm{~km}$ and $124 \mathrm{~km}$ northeast of Shiraz, respectively, and these quarries are located at a distance of 34 $\mathrm{km}$ from each other (Ataei, 2008).

The quarries started working about 30 years ago and now the Dehbid mine has 28 extraction steps and the Shayan mine has 18 extraction benches. Figure 2 shows 


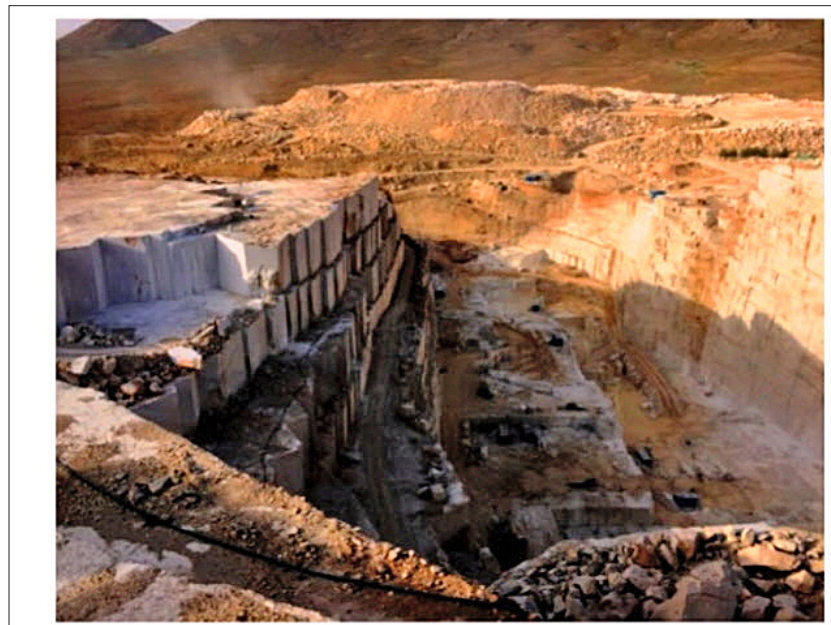

A

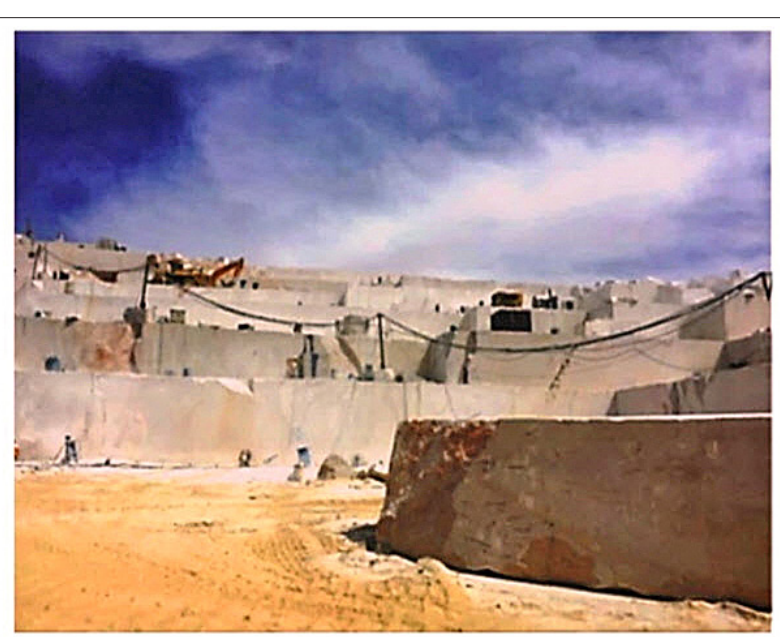

$\mathrm{B}$

Figure 2: Dehbid Marble Mine (A) and Shayan Marble Mine (B).

Table 2: Results of samples analysis for the case studies quarries

\begin{tabular}{|c|c|c|c|c|c|c|c|c|c|}
\hline \multirow[b]{2}{*}{ Case studies } & \multirow{2}{*}{$\begin{array}{l}\text { Working face } \\
\text { No. }\end{array}$} & $C_{1}$ & $C_{2}$ & $C_{3}$ & $C_{4}$ & $C_{5}$ & $C_{6}$ & $C_{7}$ & $C_{8}$ \\
\hline & & $\begin{array}{c}\text { Gs } \\
(\mathrm{mm})\end{array}$ & $\begin{array}{l}\mathrm{H} \\
\text { (n) }\end{array}$ & $\begin{array}{c}\mathrm{P} \\
(\%)\end{array}$ & $\begin{array}{l}\text { Wa } \\
(\%)\end{array}$ & $\begin{array}{l}\text { Qc } \\
(\%)\end{array}$ & $\mathrm{A}(\%)$ & $\begin{array}{c}\text { BTS } \\
(\mathrm{MPa})\end{array}$ & $\begin{array}{c}\text { UCS } \\
(\mathrm{MPa})\end{array}$ \\
\hline \multirow{4}{*}{ Dehbid } & $\mathrm{S}_{1}$ & 1.5 & 68 & 1 & 0.5 & 0.9 & 3.4 & 8.6 & 92 \\
\hline & $\mathrm{S}_{2}$ & 1.3 & 70 & 0.8 & 0.4 & 0.9 & 2.8 & 9 & 99 \\
\hline & $\mathrm{S}_{3}$ & 1 & 71 & 0.5 & 0.5 & 0.8 & 3.5 & 9.1 & 100 \\
\hline & $\mathrm{S}_{4}$ & 0.5 & 72 & 1.5 & 0.8 & 0.9 & 3.1 & 8 & 90 \\
\hline \multirow{3}{*}{ Shayan } & $\mathrm{S}_{5}$ & 1.5 & 76 & 0.8 & 0.8 & 2.3 & 2.4 & 8.4 & 109 \\
\hline & $\mathrm{S}_{6}$ & 0.5 & 73 & 0.8 & 0.3 & 2.1 & 2 & 8.2 & 105 \\
\hline & $\mathrm{S}_{7}$ & 0.3 & 77 & 0.3 & 0.3 & 2.2 & 2.3 & 8.9 & 111 \\
\hline
\end{tabular}

a close view of the two quarries. Seven laboratory marble samples of standard dimensions, including 4 samples from the Dehbid marble mine and 3 samples from the Shayan marble mine were collected. Each sample was placed under experiment to determine physical, chemical and mechanical properties under standard conditions. Seven active mining faces extracted in the mentioned quarries (4 faces in Dehbid mine and 3 in Shayan mine) were studied in this research. It should be noted that the extraction operation in the mentioned faces was done by a model of a chainsaw cutting machine. A sample with dimensions of $30 \times 30 \times 30 \mathrm{~cm}$ was taken from each face to be sent to the laboratory for physical and mechanical experiments, and field measurements were simultaneously done along with the collection operation.

\subsection{Physical and mechanical characteristics}

Among the significant parameters on the performance of the chainsaw cutting machine are the physical and mechanical properties. Important physical parameters include grain size (Gs), equal quartz content (Qc), porosity $(\mathrm{P})$ and water absorption percentage (Wa). Important mechanical parameters are the uniaxial compressive strength (UCS), Brazilian tensile strength (BTS), Los
Angeles abrasion (A) and Schmidt hammer hardness (H). The results of the mechanical and physical tests for samples No. 1 to No. 4 of the Dehbid marble mine and No. 5 to No. 7 of the Shayan marble mine are given in Table 2.

\section{Sawability study using PROMETHEE Multi Criteria Model}

In order to select the best option using the PROMETHEE method, the following steps were performed to evaluate the cutting capability of the studied faces in the Dehbid and Shayan quarries:

\subsection{Decision matrix}

In the first step, the decision matrix including criteria (C1: C8) and problem options (S1: S7) was established based on the results of field and laboratory studies. Table 3 shows the research related decision matrix.

In addition, each option was evaluated against each of the criteria. Then, in order for all the data to have the same dimension, dimensioning operations were performed on them. Table 4 indicates the dimensionless data. 


\subsection{Determining the weight of the criteria}

Based on Equation 1, the weight of each criterion should be determined according to their degree of sig-

Table 3: Decision Matrix schema.

\begin{tabular}{|l|c|c|c|c|c|c|c|c|}
\hline & C1 & C2 & C3 & C4 & C5 & C6 & C7 & C8 \\
\hline S1 & 1.5 & 68 & 1 & 0.5 & 0.9 & 3.4 & 8.6 & 92 \\
\hline S2 & 1.3 & 70 & 0.8 & 0.4 & 0.9 & 2.8 & 9 & 99 \\
\hline S3 & 1 & 71 & 0.5 & 0.5 & 0.8 & 3.5 & 9.1 & 100 \\
\hline S4 & 0.5 & 72 & 1.5 & 0.8 & 0.9 & 3.1 & 8 & 90 \\
\hline S5 & 1.5 & 76 & 0.8 & 0.8 & 2.3 & 2.4 & 8.4 & 109 \\
\hline S6 & 0.5 & 73 & 0.8 & 0.3 & 2.1 & 2 & 8.2 & 105 \\
\hline S7 & 0.3 & 77 & 0.3 & 0.3 & 2.2 & 2.3 & 8.9 & 111 \\
\hline
\end{tabular}

Table 4: Dimensioning the decision matrix.

\begin{tabular}{|l|c|c|c|c|c|c|c|c|}
\hline & C1 & C2 & C3 & C4 & C5 & C6 & C7 & C8 \\
\hline S1 & 0.537 & 0.354 & 0.426 & 0.343 & 0.214 & 0.453 & 0.377 & 0.343 \\
\hline S2 & 0.466 & 0.364 & 0.340 & 0.274 & 0.214 & 0.373 & 0.395 & 0.371 \\
\hline S3 & 0.385 & 0.370 & 0.213 & 0.343 & 0.190 & 0.466 & 0.399 & 0.373 \\
\hline S4 & 0.179 & 0.375 & 0.639 & 0.549 & 0.214 & 0.413 & 0.351 & 0.336 \\
\hline S5 & 0.537 & 0.396 & 0.340 & 0.549 & 0.548 & 0.319 & 0.368 & 0.407 \\
\hline S6 & 0.179 & 0.380 & 0.340 & 0.206 & 0.501 & 0.266 & 0.361 & 0.392 \\
\hline S7 & 0.107 & 0.401 & 0.127 & 0.206 & 0.524 & 0.306 & 0.391 & 0.414 \\
\hline
\end{tabular}

Table 5: Weights set for criteria.

\begin{tabular}{|l|c|c|c|c|c|c|c|c|}
\hline Criteria & C1 & C2 & C3 & C4 & C5 & C6 & C7 & C8 \\
\hline weight & 0.2 & 0.15 & 0.1 & 0.05 & 0.1 & 0.12 & 0.13 & 0.15 \\
\hline
\end{tabular}

nificance and the extent of cutting capability by a chainsaw saw. The weight of the criteria is determined in such a way that the total weight of the criteria equals one (see Table 5; Ataei 2010; Rad et al., 2012). In this study the weight of the criteria was determined based on the experience and knowledge of the authors using simple weighting methods.

$$
\sum_{j=1}^{k} W_{j}=1
$$

Where $\mathrm{Wj}$ is the degree of importance of each of the criteria and $\mathrm{k}$ is the number of criteria.

\subsection{Pair comparison of options}

In the PROMETHEE method, the options are compared in a two-by-two way in terms of each of the criteria. In this method, the discrepancy between the two-bytwo evaluation of options is taken into account in terms of the intended criterion. The preference function for each criterion converts the numerical difference between the evaluation of the two options into a number between 0 and 1 (Ataei 2010). Table 6 shows the paired comparison matrix of options in terms of each of the criteria.

\subsection{Determining cumulative preferential indicators}

Preferential-cumulative indices are determined based on Equations 2 and 3 (Ataei 2010):

Table 6: Paired comparison matrix of options.

\begin{tabular}{|l|c|c|c|c|c|c|c|c|c|c|c|c|c|c|c|c|c|}
\hline & C1 & C2 & C3 & C4 & C5 & C6 & C7 & C8 & & C1 & C2 & C3 & C4 & C5 & C6 & C7 & C8 \\
\hline$(\mathrm{S} 2) \rightarrow(\mathrm{S} 1)$ & 1 & 1 & 1 & 1 & 0 & 0 & 1 & 1 & $(\mathrm{~S} 2) \rightarrow(\mathrm{S} 7)$ & 0 & 0 & 0 & 0 & 0 & 1 & 1 & 0 \\
\hline$(\mathrm{S} 1) \rightarrow(\mathrm{S} 2)$ & 0 & 0 & 0 & 0 & 0 & 1 & 1 & 1 & $(\mathrm{~S} 4) \rightarrow(\mathrm{S} 3)$ & 1 & 1 & 0 & 0 & 1 & 0 & 0 & 0 \\
\hline$(\mathrm{S} 3) \rightarrow(\mathrm{S} 1)$ & 1 & 1 & 1 & 0 & 0 & 1 & 1 & 1 & $(\mathrm{~S} 3) \rightarrow(\mathrm{S} 4)$ & 0 & 0 & 1 & 1 & 0 & 1 & 1 & 1 \\
\hline$(\mathrm{S} 1) \rightarrow(\mathrm{S} 3)$ & 0 & 0 & 0 & 0 & 1 & 0 & 0 & 0 & $(\mathrm{~S} 5) \rightarrow(\mathrm{S} 3)$ & 0 & 1 & 0 & 0 & 1 & 0 & 0 & 1 \\
\hline$(\mathrm{S} 4) \rightarrow(\mathrm{S} 1)$ & 1 & 1 & 0 & 0 & 0 & 0 & 0 & 0 & $(\mathrm{~S} 3) \rightarrow(\mathrm{S} 5)$ & 1 & 0 & 1 & 1 & 0 & 1 & 1 & 0 \\
\hline$(\mathrm{S} 1) \rightarrow(\mathrm{S} 4)$ & 0 & 0 & 1 & 1 & 0 & 1 & 1 & 1 & $(\mathrm{~S} 6) \rightarrow(\mathrm{S} 3)$ & 1 & 1 & 0 & 1 & 1 & 0 & 0 & 1 \\
\hline $\mathrm{S} 5) \rightarrow(\mathrm{S} 1)$ & 0 & 1 & 1 & 0 & 1 & 0 & 0 & 1 & $(\mathrm{~S} 3) \rightarrow(\mathrm{S} 6)$ & 0 & 0 & 1 & 0 & 0 & 1 & 1 & 0 \\
\hline$(\mathrm{S} 1) \rightarrow(\mathrm{S} 5)$ & 0 & 0 & 0 & 1 & 0 & 1 & 1 & 0 & $(\mathrm{~S} 7) \rightarrow(\mathrm{S} 3)$ & 1 & 1 & 1 & 1 & 1 & 0 & 0 & 1 \\
\hline$(\mathrm{S} 6) \rightarrow(\mathrm{S} 1)$ & 1 & 1 & 1 & 1 & 1 & 0 & 0 & 1 & $(\mathrm{~S} 3) \rightarrow(\mathrm{S} 7)$ & 0 & 0 & 0 & 0 & 0 & 1 & 1 & 1 \\
\hline$(\mathrm{S} 1) \rightarrow(\mathrm{S} 6)$ & 0 & 0 & 0 & 0 & 0 & 1 & 1 & 0 & $(\mathrm{~S} 5) \rightarrow(\mathrm{S} 4)$ & 0 & 1 & 1 & 0 & 1 & 0 & 1 & 1 \\
\hline$(\mathrm{S} 7) \rightarrow(\mathrm{S} 1)$ & 1 & 1 & 1 & 1 & 1 & 0 & 1 & 1 & $(\mathrm{~S} 4) \rightarrow(\mathrm{S} 5)$ & 1 & 0 & 0 & 0 & 0 & 1 & 0 & 0 \\
\hline$(\mathrm{S} 1) \rightarrow(\mathrm{S} 7)$ & 0 & 0 & 0 & 0 & 0 & 1 & 0 & 0 & $(\mathrm{~S} 6) \rightarrow(\mathrm{S} 4)$ & 0 & 1 & 1 & 1 & 1 & 0 & 1 & 1 \\
\hline$(\mathrm{S} 3) \rightarrow(\mathrm{S} 2)$ & 1 & 1 & 1 & 0 & 0 & 1 & 1 & 1 & $(\mathrm{~S} 4) \rightarrow(\mathrm{S} 6)$ & 0 & 0 & 0 & 0 & 0 & 1 & 0 & 0 \\
\hline$(\mathrm{S} 2) \rightarrow(\mathrm{S} 3)$ & 0 & 0 & 0 & 1 & 1 & 0 & 0 & 0 & $(\mathrm{~S} 7) \rightarrow(\mathrm{S} 4)$ & 1 & 1 & 1 & 1 & 1 & 0 & 1 & 1 \\
\hline$(\mathrm{S} 4) \rightarrow(\mathrm{S} 2)$ & 1 & 1 & 0 & 0 & 0 & 1 & 0 & 0 & $(\mathrm{~S} 4) \rightarrow(\mathrm{S} 7)$ & 0 & 0 & 0 & 0 & 0 & 1 & 0 & 0 \\
\hline$(\mathrm{S} 2) \rightarrow(\mathrm{S} 4)$ & 0 & 0 & 1 & 1 & 0 & 0 & 1 & 1 & $(\mathrm{~S} 6) \rightarrow(\mathrm{S} 5)$ & 1 & 0 & 0 & 1 & 0 & 0 & 0 & 0 \\
\hline$(\mathrm{S} 5) \rightarrow(\mathrm{S} 2)$ & 0 & 1 & 0 & 0 & 1 & 0 & 0 & 1 & $(\mathrm{~S} 5) \rightarrow(\mathrm{S} 6)$ & 0 & 1 & 0 & 0 & 1 & 1 & 1 & 1 \\
\hline$(\mathrm{S} 2) \rightarrow(\mathrm{S} 5)$ & 1 & 0 & 0 & 1 & 0 & 1 & 1 & 0 & $(\mathrm{~S} 7) \rightarrow(\mathrm{S} 5)$ & 1 & 1 & 1 & 1 & 0 & 0 & 1 & 1 \\
\hline$(\mathrm{S} 6) \rightarrow(\mathrm{S} 2)$ & 1 & 1 & 0 & 1 & 1 & 0 & 0 & 1 & $(\mathrm{~S} 5) \rightarrow(\mathrm{S} 7)$ & 0 & 0 & 0 & 0 & 1 & 1 & 0 & 0 \\
\hline$(\mathrm{S} 2) \rightarrow(\mathrm{S} 6)$ & 0 & 0 & 0 & 0 & 0 & 1 & 1 & 0 & $(\mathrm{~S} 7) \rightarrow(\mathrm{S} 6)$ & 1 & 1 & 1 & 0 & 1 & 1 & 1 & 1 \\
\hline$(\mathrm{S} 7) \rightarrow(\mathrm{S} 2)$ & 1 & 1 & 1 & 1 & 1 & 0 & 0 & 1 & $(\mathrm{~S} 6) \rightarrow(\mathrm{S} 7)$ & 0 & 0 & 0 & 0 & 0 & 0 & 0 & 0 \\
\hline
\end{tabular}


Table 7: Determining the cumulative preference index.

\begin{tabular}{|c|c|c|c|c|c|c|c|c|c|c|c|c|c|c|c|c|c|c|c|}
\hline & & 22 & C3 & & 5 & C6 & $\mathrm{C} 7$ & C8 & $\pi$ & & $\mathrm{C} 1$ & $\mathrm{C} 2$ & 3 & $\mathrm{C} 4$ & 55 & C6 & $\mathrm{C} 7$ & C8 & \\
\hline 2) & 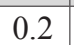 & 15 & 0.1 & 05 & 0 & 0 & 0.13 & 0.15 & 0.78 & ( & & & & 0 & & 0.12 & 0.13 & 0 & 0.2 \\
\hline & & & & & ( & 12 & & & 2 & & 2 & 0.15 & & & 0.1 & & & 0.15 & \\
\hline & & & 0. & & & & 0.13 & 0.15 & & & & & 1 & 0.0 & & 2 & & & \\
\hline & & & 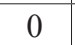 & & 0. & & & & & & & 0.1 & & & 0.1 & & & 0.1 & \\
\hline & & & 0 & & & & & & & & & & & 0 & & & & & \\
\hline & & & & & & & 0.13 & & & & & & & & & & & & \\
\hline & & & & & & & & & & & & & & & & & & & \\
\hline & & & & & & & & & & & & & & 0.0 & & & & & \\
\hline & & & & & & & & & 5 & & & & & & & & & & \\
\hline & & & & & & & & & & & & & . & & 0.1 & & 0. & & \\
\hline & & & 0 & & 0 & & 0.13 & 0. & & & & & & & & 0.1 & & & \\
\hline & & & & & & & & & & & 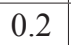 & 0. & 0.1 & 0.05 & 0.1 & & 0.13 & 0. & \\
\hline & & & 0 & & & 2 & 0.13 & 0. & 0 & & & & 0 & & & 0.1 & & & \\
\hline & & & 0 & & 0 & & & & 5 & & 0.2 & 0.1 & 0.1 & 0.05 & 0.1 & & 0.13 & 0. & \\
\hline & 2 & & & & & & & & 0.47 & & & & & & & 0.1 & & & \\
\hline & 0 & 0 & 0.1 & & & 0 & 0.13 & & 0.43 & & 0.2 & & & 0.0 & & & & & \\
\hline & 0 & & 0 & 0 & 0.1 & & 0 & 0.15 & t & & & & & & 0.1 & 0.12 & ( & & \\
\hline 55) & & 0 & 0 & & 0 & 0.12 & 0.13 & 0 & 0. & & 0.2 & 0.15 & 0.1 & 0.0 & & & 0.13 & 0. & \\
\hline ) & 800 & & 0 & 0. & 0 & 0 & 0 & 0.15 & 0.65 & & & & 0 & & 1 & & & & 0. \\
\hline & 0 & 0 & 0 & 0 & 0 & 12 & 0.13 & & 0. & & 0.2 & 0.15 & .1 & & 0.1 & 0.12 & 0.13 & 0.15 & 0. \\
\hline & & & & & & & & & & $\rightarrow$ & & & & & & & & 0 & \\
\hline
\end{tabular}

Table 8: Calculation of input and output currents.

\begin{tabular}{|l|c|c|c|c|c|c|c|l|}
\hline & $\mathrm{S}_{1}$ & $\mathrm{~S}_{2}$ & $\mathrm{~S}_{3}$ & $\mathrm{~S}_{4}$ & $\mathrm{~S}_{5}$ & $\mathrm{~S}_{6}$ & $\mathrm{~S}_{7}$ & Output currents \\
\hline $\mathrm{S}_{1}$ & 0 & 0.78 & 0.85 & 0.35 & 0.5 & 0.75 & 0.88 & 4.11 \\
\hline $\mathrm{S}_{2}$ & 0.12 & 0 & 0.85 & 0.47 & 0.4 & 0.65 & 0.75 & 3.24 \\
\hline $\mathrm{S}_{3}$ & 0.1 & 0.15 & 0 & 0.45 & 0.4 & 0.65 & 0.75 & 2.5 \\
\hline $\mathrm{S}_{4}$ & 0.55 & 0.43 & 0.55 & 0 & 0.95 & 0.88 & 0.88 & 4.24 \\
\hline $\mathrm{S}_{5}$ & 0.3 & 0.5 & 0.6 & 0.32 & 0 & 0.25 & 0.78 & 2.75 \\
\hline $\mathrm{S}_{6}$ & 0.25 & 0.25 & 0.35 & 0.12 & 0.65 & 0 & 0.95 & 2.75 \\
\hline $\mathrm{S}_{7}$ & 0.12 & 0.25 & 0.25 & 0.12 & 0.22 & 0 & 0 & 0.96 \\
\hline Input Currents & 1.44 & 2.36 & 3.45 & 1.83 & 3.12 & 3.18 & 4.99 & \\
\hline
\end{tabular}

$$
\forall a, b \in A,\left\{\begin{array}{l}
\pi(a, b)=\sum_{j=1}^{k} P_{j}(a, b) w_{j} \\
\pi(b, a)=\sum_{j=1}^{k} P_{j}(b, a) w_{j}
\end{array}\right.
$$

Where $\mathrm{p}$ is a inception of exacting preference, $\pi(a, b)$ is which degree $a$ is preferred to $b$ over all the criteria and $\pi(b, a)$ how $b$ is preferred to $a$, that $\mathrm{a}$ and $\mathrm{b}$ belong to the set of A.

$$
\forall a, b \in A,\left\{\begin{array}{l}
\pi(a, a)=0 \\
0 \leq \pi(a, b) \leq 1 \\
0 \leq \pi(b, a) \leq 1 \\
0 \leq \pi(a, b)+\pi(b, a) \leq 1
\end{array}\right.
$$

It is clear that:

$\pi(a, b) \rightarrow 0$ Option " $a$ " has a weak overall advantage over option $b$. $\pi(a, b) \rightarrow 1$ Option " $a$ " has a strong overall advantage over option $b$.

According to Equations 2 and 3, the cumulative preference index for options was obtained as Table 7.

\subsection{Partial and complete ranking of options}

At this stage, in order to rank the options, the preference of each option over the other options, as well as the preference of all options over the intended option should be specified. The preference of each option over the other options is called positive ranking current or output current and the preference of other options over the intended option is named negative ranking current or input current. A positive ranking current or output current suggests how much the option has priority over the other options. This current is, in fact, the power of the intended option in the ranking, and the higher the value for the option, the better the intended option. Hence, the option 
with the largest output current is the superior option. Negative ranking current or input current also shows the degree to which other options have priority over the intended option. This current is in fact the weakness of the intended option in the ranking, and the lower its degree on the intended option, the better the intended option will be. Therefore, the option with the smallest input current is the best option (Ataei 2010). Table 8 shows how to estimate the input and output currents.

Finally, according to the obtained values for the input and output currents, the net current and the final ranking of the options were obtained. Table 9 shows the net stream values and the ranking of options.

According to Table 9, the number one face of the Dehbid mine with its values of net current has output

Table 9: Ranking of studied stopes in the Dehbid and Shayan quarries.

\begin{tabular}{|l|l|l|l|l|l|}
\hline Mine & Options & $\begin{array}{l}\text { Net } \\
\text { current }\end{array}$ & $\begin{array}{l}\text { Output } \\
\text { current }\end{array}$ & $\begin{array}{l}\text { Input } \\
\text { current }\end{array}$ & Ranking \\
\hline \multirow{4}{*}{ Dehbid } & S1 & 2.67 & 4.11 & 1.44 & 1 \\
\cline { 2 - 6 } & S2 & 0.88 & 3.24 & 2.36 & 3 \\
\cline { 2 - 6 } & S3 & -0.95 & 2.5 & 3.45 & 6 \\
\cline { 2 - 6 } & S4 & 2.41 & 4.24 & 1.83 & 2 \\
\hline \multirow{4}{*}{ Shayan } & S5 & -0.37 & 2.75 & 3.12 & 4 \\
\cline { 2 - 6 } & S6 & -0.61 & 2.57 & 3.18 & 5 \\
\cline { 2 - 6 } & S7 & -4.03 & 0.96 & 4.99 & 7 \\
\hline
\end{tabular}

and input currents of 2.67, 4.11 and 1.44, respectively, and the number five face of the Shayan mine with values of $-0.37,2.75$ and 3.18 , respectively. The net steams are introduced as the best faces in the studied quarries in terms of production rate capability.

\section{Model validation}

In order to validate the results of the proposed decision model, field studies were performed on the studied faces to measure the production rate of the chainsaw machine performance. In the Dehbid mine, 9 chainsaw cutting machines were produced by the Fantini company of different models and in the Shayan mine, 3 chainsaw cutting machines were produced by the Fantini company and 2 chainsaw cutting machines produced by the Benetti company were used to extract dimension stones. The types of production models of chainsaw machines by different companies have different properties selected depending on the geological conditions, mineral characteristics, excavation plan, climatic conditions, etc. The proportion between the extraction operation parameters and dimension characteristics of a chainsaw cutting machine reduces energy consumption and cutting time, improves work technically and economically (reduced cost of each stone block), increases productivity in terms of production rate, etc. The key operating parameters controlled by the operator are the cart speed, the speed of the

Table 1o: Characteristics of the machines used in this study

\begin{tabular}{|l|c|c|c|c|c|c|c|c|c|c|}
\hline \multirow{2}{*}{ Model } & BL & ECD & UCL & EP & MW & CS & ChS & CW & AR & HTV \\
\cline { 2 - 25 } & $(\mathrm{m})$ & $(\mathrm{m})$ & $(\mathrm{m})$ & $(\mathrm{KW})$ & $(\mathrm{kg})$ & $(\mathrm{cm} / \mathrm{min})$ & $(\mathrm{m} / \mathrm{s})$ & $(\mathrm{mm})$ & $\circ$ & \multicolumn{1}{c}{360} \\
\hline Fantini-70RA/P & 7.2 & 5 & 6.3 & 50 & 10500 & $0-13$ & $0-0.7$ & 38 & 360 \\
\hline
\end{tabular}

BL: Blade length, UCL: Useful cutting length, EP: Electrical power, MW: Machine weight with rail, CS: Cart speed,

ChS: Chain speed, CW: Cutting width, AR: Arm rotation, HTV: Hydraulic tank volume

Table 11: Results of field surveys of the studied benches

\begin{tabular}{|l|c|c|c|c|c|c|c|c|c|c|}
\hline \multirow{3}{*}{ No. } & \multicolumn{3}{|c|}{$\begin{array}{l}\text { Operation } \\
\text { condition }\end{array}$} & \multicolumn{4}{c|}{ Production Rate $\left(m^{2} / h r\right)$} \\
\cline { 2 - 12 } & AR & ChS & CS & S1 & S2 & S3 & S4 & S5 & S6 & S7 \\
\hline 1 & 65 & 0.125 & 8 & 3.8 & 3.5 & 3.7 & 3.2 & 2.6 & 2.8 & 1.8 \\
\hline 2 & 70 & 0.125 & 8 & 4.5 & 4 & 4.3 & 3.5 & 2.8 & 3 & 1.8 \\
\hline 3 & 75 & 0.125 & 8 & 4.85 & 4.1 & 4.3 & 3.6 & 2.9 & 3 & 2.4 \\
\hline 4 & 80 & 0.125 & 8 & 4.01 & 3.8 & 4.3 & 3.8 & 2.6 & 2.9 & 2 \\
\hline 5 & 85 & 0.125 & 8 & 4 & 3.5 & 3.3 & 2.9 & 2.4 & 2.4 & 2 \\
\hline 6 & 75 & 0.1 & 8 & 3.4 & 3 & 2.8 & 2.8 & 2.4 & 2 & 1.6 \\
\hline 7 & 75 & 0.117 & 8 & 4.1 & 3.5 & 2.9 & 3.4 & 2.7 & 2.4 & 2 \\
\hline 8 & 75 & 0.125 & 8 & 4.85 & 4.2 & 3.5 & 4 & 3 & 2.9 & 2.3 \\
\hline 9 & 75 & 0.133 & 8 & 4.85 & 4.2 & 3.5 & 4.2 & 3.1 & 2.9 & 2.4 \\
\hline 10 & 75 & 0.142 & 8 & 4.85 & 4.2 & 3.5 & 4.2 & 3.1 & 2.9 & 2.4 \\
\hline 11 & 75 & 0.125 & 6.5 & 3 & 3 & 3 & 2.9 & 2.2 & 2.1 & 1.4 \\
\hline 12 & 75 & 0.125 & 7 & 4 & 3.5 & 3.4 & 2.3 & 2.5 & 2.5 & 1.8 \\
\hline 13 & 75 & 0.125 & 7.5 & 4.73 & 3.9 & 4 & 3.4 & 2.9 & 2.6 & 2.2 \\
\hline 14 & 75 & 0.125 & 8 & 4.95 & 4.1 & 4.3 & 4 & 2.9 & 2.8 & 2.5 \\
\hline
\end{tabular}

chain and the angle of the blade. The desired values of the operating parameters are based on the suggestions made by the manufacturing company and the experience of the chainsaw operator. Operator skills is one of the effective parameters in the stone cutting process. In order for the field study conditions to remain constant, the chainsaw machine used in both quarries, which includes 7 working faces, was selected from a model with the same properties. Figure 3 shows the chainsaw cutting machine used in these quarries. The characteristics of the chain saw machine used in this study are given in Table 10. The results of field studies on 7 studied working faces are given in Table 11.

According to Table 11, it can be seen that under constant operating conditions in the Dehbid and Shayan quarries, from among 15 different conditions of chainsaw cutting machine, the No. 1 face of Dehbid mine had the highest production rate in more than $80 \%$ compared to other faces in this mine and face No. 5 from the Shay- 


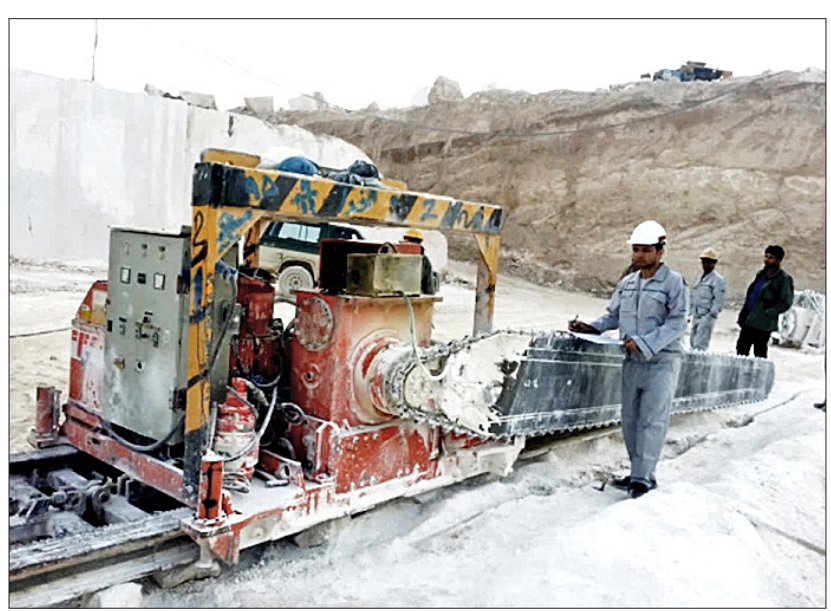

Figure 3: Chainsaw cutting machine was used in the case study quarries.

an mine had the highest such production rate in more than $65 \%$ of operating conditions compared to the other two faces from this mine.

\section{Conclusions}

In this research, attempts were done to assess the cutting capability of dimension stones extracted by a chain saw cutting machine in the Dehbid and Shayan quarries. Finally, the cutting capability of the seven faces included in this study were graded according to physical and mechanical characteristics including: uniaxial compressive strength of the stone, Brazilian tensile strength, Los Angeles abrasion, quartz percentage, water absorption percentage, porosity, Schmidt hardness and granule size by using a PROMETHEE decision model. The study results showed that face No. 1 of the Dehbid mine with some net currents, output and input currents of 2.67, 4.11 and 1.44, respectively, and face No. 5 of the Shayan mine with values of $-0.37,2.75$ and 3.18 were introduced as the most suitable face machine with high cutting capability in the studied quarries. Then, in order to validate the results of the recommended decision model, field studies were conducted under different operating conditions of the chainsaw cutting machine in the studied quarries. The results of the model validation (comparison of the ranking obtained from the decision model with those of the production rate registered in the mine) showed that in more than 80 and $65 \%$ of the cases intended for the face chainsaw cutting machine, selected works in the Dehbid and Shayan quarries accounted for the highest production rates, respectively. Finally, this study shows that the cutting-capability of the studied faces can be evaluated based on physical and mechanical properties using decision-making models.

\section{Acknowledgment}

We would like to express our deepest thanks to Professor Mahdi Ghaem for his excellent advice.

\section{References}

Agus, M., Bortolussi, A., Careddu, N., Ciccu, R., Grosso, B., \& Massacci, G. (2003): Influence of stone properties on diamond wire performance. In: Singhal, Fytas and Chiwetelu. (eds.): In Fourth international conference on computer applications in the minerals industries (CAMI 2003): Calgary, Canada, September 2003, 12 p.

Akhyani, M., Sereshki, F., Mikaeil, R., \& Taji, M. (2017): Evaluation of Cutting Performance of Diamond Saw Machine Using Artificial Bee Colony (ABC) Algorithm. International Journal of Mining and Geo-Engineering, 51, 2, 185-190.

Akhyani, M., Sereshki, F., \& Mikaeil, R. (2018): An investigation of the effect of toughness and brittleness indexes on ampere consumption and wear rate of a circular diamond saw. Rudarsko-geološko-naftni zbornik (The Mining-Geology-Petroleum Engineering Bulletin), 33,4, 85-93. https: //doi.org/10.17794/rgn.2018.4.8.

Akhyani, M., Mikaeil, R., Sereshki, F., \& Taji, M. (2019): Combining fuzzy RES with GA for predicting wear performance of circular diamond saw in hard rock cutting process. Journal of Mining and Environment, 10, 3, 559-574. https://doi.org/10.22044/jme.2017.5770.1388.

Almasi, S. N., Bagherpour, R., Mikaeil, R., Ozcelik, Y., \& Kalhori, H. (2017): Predicting the building stone cutting rate based on rock properties and device pullback amperage in quarries using M5P model tree. Geotechnical and Geological Engineering, 35, 4, 1311-1326. https://doi.org/10.1007/ s10706-017-0177-0.

Almasi, S. N., Bagherpour, R., Mikaeil, R., \& Ozcelik, Y. (2017): Analysis of bead wear in diamond wire sawing considering the rock properties and production rate. Bulletin of Engineering Geology and the Environment, 76, 4, 1593-1607. https://doi.org/10.1007/s10064-017-1057-9.

Almasi, S. N., Bagherpour, R., Mikaeil, R., \& Ozcelik, Y. (2017): Developing a new rock classification based on the abrasiveness, hardness, and toughness of rocks and PA for the prediction of hard dimension stone sawability in quarrying. Geosystem Engineering, 20,6, 295-310. https://doi. org/10.1080/12269328.2017.1278727.

Aryafar, A., \& Mikaeil, R. (2016): Estimation of the ampere consumption of dimension stone sawing machine using of artificial neural networks. International Journal of Mining and Geo-Engineering, 50, 1, 121-130.

Aryafar, A., Mikaeil, R., Haghshenas, S. S., \& Haghshenas, S. S. (2018): Application of metaheuristic algorithms to optimal clustering of sawing machine vibration. Measurement, 124, 20-31. https://doi.org/10.1016/j.measurement.2018. 03.056.

Aryafar, A., Mikaeil, R., \& Shafiee Haghshenas, S. (2018): Utilization of soft computing for evaluating the performance of stone sawing machines, Iranian Quarries. International Journal of Mining and Geo-Engineering, 52, 1, 31-36. https:// doi.org/10.22059/IJMGE.2017.233493.594673.

Ataei, M. (2008): Extraction of dimension stones. $1^{\text {th }}$ Edition. Shahrood University of Technology Publications. Shahrood. Iran. 296pp. 
Ataei, M. (2010): Multi-criteria decision-making methods Shahrood University of Technology Publications. Shahrood. Iran. 327 pp.

Ataei, M., Mikaiel, R., Sereshki, F., \& Ghaysari, N. (2011): Predicting the production rate of diamond wire saw using statistical analysis. Arabian Journal of Geosciences, 5,6, 1289-1295. https://doi.org/10.1007/s12517-010-0278-z.

Ataei, M., Mikaeil, R., Hoseinie, S. H., \& Hosseini, S. M. (2012): Fuzzy analytical hierarchy process approach for ranking the sawability of carbonate rock. International Journal of Rock Mechanics and Mining Sciences, 50, 8393. https://doi.org/10.1016/j.ijrmms.2011.12.002.

Burgess, R. B.\& Birle, J. D., (1978): Circular sawing granite with diamond saw blades". In: Proceedings of the Fifth Industrial Diamond Seminar, Tokyo, Japon. 3-10.

Birle, J. D., \& Ratterman, E. (1986): An approximate ranking of the sawability of hard building stones based on laboratory tests. Dimension Stone Magazine, 3, 1, 3-29.

Buyuksagis, I. S., \& Goktan, R. M. (2005): Investigation of marble machining performance using an instrumented block-cutter. Journal of Materials Processing Technology, 169, 2, 258-262. https://doi.org/10.1016/j.jmatprotec.2005.03.014

Buyuksagis, I. S. (2007): Effect of cutting mode on the sawability of granites using segmented circular diamond sawblade. Journal of Materials Processing Technology, 183, 2-3, 399406. https://doi.org/10.1016/j.jmatprotec.2006.10.034.

Cai, O., Careddu, N., Mereu, M., \& Mulas, I. (2007): The influence of operating parameters on the total productivity of diamond wire in cutting granite. IDR. Industrial Diamond Review, 3, 25-32.

Careddu, N., Cai, O., (2014): Granite sawing by diamond wire: from Madrigali "bicycle" to modern multi-wires. Diamante - Applicazioni \& Tecnologia, 79, 33-50.

Careddu, N., Lanceni, G., (2015): The sawing of granite blocks with gang-saw: strong points of the traditional technology. Marmo Macchine Attrezzature E Accessori Vari., $245,12-25$

Careddu, N., Cai, O., Perra, E.S., (2018): Performance and issues of diamond wire in ornamental basalt quarries. Geoingegneria Ambientale e Mineraria, 155, 3, 85-92.

Careddu, N., Perra, E.S., Masala, O., (2019): Diamond wire sawing in ornamental basalt quarries: technical, economic and environmental considerations. Bulletin of Engineering Geology and the Environment. 78, 557-568. https://doi. org/10.1007/s10064-017-1112-6.

Clausen, R., Wang, C. Y., \& Meding, M. (1996): Characteristics of acoustic emission during single diamond scratching of granite. Industrial Diamond Review, 56, 570, 96-9.

Ciccu R, Agus M, Bortolussi A, Massacci G, Careddu N (1998): Diamond wire sawing of hard rocks. In: Superabrasives and CVD diamond, theory and applications, 11,4, 365-377.

Copur, H., Balci, C., Bilgin, N., Tumac, D., Feridunoglu, C., Dincer, T., \& Serter, A. (2006): Cutting performance of chain saws in quarries and laboratory. In: Cardu M, Ciccu R, Lovera E, Michelotti E, (eds.): In Proceedings of the 15th International Symposium on Mine Planning and Equipment Selection, MPES, Torino, Italy.1324-9.
Copur, H., Balci, C., Tumac, D., \& Bilgin, N. (2011): Field and laboratory studies on natural stones leading to empirical performance prediction of chain saw machines. International Journal of Rock Mechanics and Mining Sciences, $48,2,269-282$.

Copur, H. (2010): Linear stone cutting tests with chisel tools for identification of cutting principles and predicting performance of chain saw machines. International Journal of Rock Mechanics and Mining Sciences, 47, 1, 104-120.

Delgado, NS., Rodriguez, R., Rio, A, Sarria I.D, Calleja L, Argandona, V.G.R. (2005): The influence of microhardness on the sawability of Pink Porrino granite (Spain). International journal of rock mechanics and mining sciences. 42, 161-166.

Dormishi, A. R., Ataei, M., Khaloo Kakaie, R., Mikaeil, R., \& Shaffiee Haghshenas, S. (2019): Performance evaluation of gang saw using hybrid ANFIS-DE and hybrid ANFISPSO algorithms. Journal of Mining and Environment, 10, 2,543-557.https://doi.org/10.22044/JME.2018.6750.1496.

Dormishi, A., Ataei, M., Mikaeil, R., Khalokakaei, R., \& Haghshenas, S. S. (2019): Evaluation of gang saws' performance in the carbonate rock cutting process using feasibility of intelligent approaches. Engineering Science and Technology, an International Journal, 22,3, 990-1000. https://doi.org/10.1016/j.jestch.2019.01.007.

Eyuboglu, A. S., Ozcelik, Y., Kulaksiz, S., \& Engin, I. C. (2003): Statistical and microscopic investigation of disc segment wear related to sawing Ankara andesites. International Journal of Rock Mechanics and Mining Sciences, $40,3,405-414$.

Ersoy, A., \& Atıc1, U. (2004): Performance characteristics of circular diamond saws in cutting different types of rocks. Diamond and Related Materials, 13, 1, 22-37. https://doi. org/10.1016/j.diamond.2003.08.016.

Ersoy, A., Buyuksagic, S., \& Atici, U. (2005): Wear characteristics of circular diamond saws in the cutting of different hard abrasive rocks. Wear, 258,9, 1422-1436. https://doi. org/10.1016/j.wear.2004.09.060.

Fener, M., Kahraman, S., \& Ozder, M. O. (2007): Performance prediction of circular diamond saws from mechanical rock properties in cutting carbonate rocks. Rock Mechanics and Rock Engineering, 40, 5, 505-517.

Gunaydin, O., Kahraman, S., \& Fener, M. (2004): Sawability prediction of carbonate rocks from brittleness indexes. Journal of the Southern African Institute of Mining and Metallurgy, 104, 4, 239-243.

Ghaysari, N., Ataei, M., Sereshki, F., \& Mikaiel, R. (2012): Prediction of performance of diamond wire saw with respect to texture characteristics of rock/Prognozowanie Wydajności Pracy Strunowej Piły Diamentowej W Odniesieniu do Charakterystyki Tekstury Skał. Archives of Mining Sciences, 57,4, 887-900.

Haghshenas, S. S., Faradonbeh, R. S., Mikaeil, R., Haghshenas, S. S., Taheri, A., Saghatforoush, A., \& Dormishi, A. (2019): A new conventional criterion for the performance evaluation of gang saw machines. Measurement, 146, 159170. https://doi.org/10.1016/j.measurement.2019.06.031. 
Hosseini, S. M., Ataei, M., Khalokakaei, R., Mikaeil, R., \& Haghshenas, S. S. (2019): Investigating the role of coolant and lubricant fluids on the performance of cutting disks (case study: hard rocks). Rudarsko-geološko-naftni zbornik (The Mining-Geology-Petroleum Engineering Bulletin), 34, 2, 13-24. https://doi.org/10.17794/rgn.2019.2.2.

Hosseini, S. M., Ataei, M., Khalokakaei, R., \& Mikaeil, R. (2020): An Experimental Investigation on the Role of Coolant and Lubricant Fluids in the Maximum Electrical Current Based upon the Rock Physical and Mechanical Properties. Geotechnical and Geological Engineering, 38, 2, 23172326. https://doi.org/10.1007/s10706-019-01101-x.

Hosseini, S. M., Ataei, M., Khalokakaei, R., Mikaeil, R., \& Haghshenas, S. S. (2020): Study of the effect of the cooling and lubricant fluid on the cutting performance of dimension stone through artificial intelligence models. Engineering Science and Technology, an International Journal, 23, 1, 71-81. https://doi.org/10.1016/j.jestch.2019.04.012.

Hekimoglu, O. Z. (2014): Studies on increasing the performance of chain saw machines for mechanical excavation of marbles and natural stones. International Journal of Rock Mechanics and Mining Sciences, 72, 230-241.

Jennings, M., \& Wright, D. (1989): Guidelines for sawing stone. Industrial Diamond Review, 49, 2, 70-5.

Kahraman, S., Fener, M., \& Gunaydin, O. (2004): Predicting the sawability of carbonate rocks using multiple curvilinear regression analysis. International journal of rock mechanics and mining sciences, 41, 7, 1123-1131. https://doi. org/10.1016/j.ijrmms.2004.04.009.

Kahraman, S., Altun, H., Tezekici, B.S., Fener, M. (2005): Sawability prediction of carbonate rocks from shear strength parameters using artificial neural networks. International Journal of Rock Mechanics \& Mining Sciences, $43,1,157-164$.

Kahraman, S., Ulker, U., \& Delibalta, M. S. (2007): A quality classification of building stones from P-wave velocity and its application to stone cutting with gang saws. Journal of the Southern African Institute of Mining and Metallurgy, 107, 7, 427-430.

Kahraman, S., \& Gunaydin, O. (2008): Indentation hardness test to estimate the sawability of carbonate rocks. Bulletin of Engineering Geology and the Environment, 67, 4, 507511. https://doi.org/10.1007/s10064-008-0162-1.

Kamran, M. A., Khoshsirat, M., Mikaeil, R., \& Nikkhoo, F. (2017): Ranking the sawability of ornamental and building stones using different MCDM methods. Journal of Engineering Research, 5,3.

Korman, T., Kujundžić, T., \& Kuhinek, D. (2015): Simulation of Chain Saw Cutting Process with Linear Cutting Machine. International journal of rock mechanics and mining sciences, 78, 283-289.

Korman, T., Kujundžić, T., Lukačić, H., \& Martinić, M. (2016): The Impact of Area and Shape of Tool Cut on Chain Saw Performance. Mining-geological-petroleum engineering bulletin, 31,3, 1-13.

Mikaeil, R., Ataei, M. A., \& Hoseinie, H. (2008): Predicting the production rate of diamond wire saws in carbonate rock cutting. IDR. Industrial Diamond Review, 68,3, 28-34.
Mikaeil, R., Ozcelik, Y., Ataei, M., \& Yousefi, R. (2011): Correlation of specific ampere draw with rock brittleness indexes in rock sawing process. Archives of Mining Sciences, 56, 4, 777-788.

Mikaeil, R., Ozcelik, Y., Yousefi, R., Ataei, M., \& Hosseini, S. M. (2013): Ranking the sawability of ornamental stone using Fuzzy Delphi and multi-criteria decision-making techniques. International Journal of Rock Mechanics and Mining Sciences, 58, 118-126. https://doi.org/10.1016/j. ijrmms.2012.09.002.

Mikaeil, R., Abdolaahi, K. M., Sadegheslam, G., \& Ataei, M. (2015): Ranking the Sawability of Dimension Stone by Using promethee, Journal of Mining and Environment, 6, 2, 263-271.

Mikaeil, R., Shaffiee Haghshenas, S., Ozcelik, Y., \& Shaffiee Haghshenas, S. (2017): Development of Intelligent Systems to Predict Diamond Wire Saw Performance. Soft Computing in Civil Engineering, 1,2, 52-69. https://doi. org/10.22115/SCCE.2017.49092.

Mikaeil, R., Sohrabian, B., \& Ataei, M. (2018a): The study of energy consumption in the dimension stone cutting process. Rudarsko-geološko-naftni zbornik (The Mining-Geology-Petroleum Engineering Bulletin), 33, 4,1-7.

Mikaeil, R., Haghshenas, S. S., Haghshenas, S. S., \& Ataei, M. (2018b): Performance prediction of circular saw machine using imperialist competitive algorithm and fuzzy clustering technique. Neural Computing and Applications, 29,6, 283-292. https://doi.org/10.1007/s00521-016-2557-4.

Mikaeil, R., Haghshenas, S. S., Ozcelik, Y., \& Gharehgheshlagh, H. H. (2018c): Performance evaluation of adaptive neuro-fuzzy inference system and group method of data handling-type neural network for estimating wear rate of diamond wire saw. Geotechnical and Geological Engineering, 36, 6, 3779-3791. https://doi.org/10.1007/s10706018-0571-2.

Mikaeil, R., Ozcelik, Y., Ataei, M., \& Shaffiee Haghshenas, S. (2019): Application of harmony search algorithm to evaluate performance of diamond wire saw. Journal of Mining and Environment, 10,1, 27-36. https://doi.org/10.22044/ JME.2016.723.

Mohammadi, J., Ataei, M., Kakaie, R., Mikaeil, R., \& Haghshenas, S. S. (2019): Performance evaluation of chain saw machines for dimension stones using feasibility of neural network models. Journal of Mining and Environment, 10,4, 1105-1119. https://doi.org/10.22044/jme.2018.7013.1542.

Mohammadi, J., Ataei, M., Kakaei, R. K., Mikaeil, R., \& Haghshenas, S. S. (2018): Prediction of the production rate of chain saw machine using the multilayer perceptron (MLP) neural network. Civil Engineering Journal, 4,7, 1575-1583.

Ozcelik, Y., Polat, E., Bayram, F., \& Ay, A. M. (2004): Investigation of the effects of textural properties on marble cutting with diamond wire. International Journal of Rock Mechanics and Mining Sciences, 41, 228-234.

Özçelik, Y. (2007): The effect of marble textural characteristics on the sawing efficiency of diamond segmented frame saws. Industrial Diamond Review, 2, 65-70.

Rad, M. Y., Haghshenas, S. S., Kanafi, P. R., \& Haghshenas, S. S. (2012): Analysis of Protection of Body Slope in the 
Rockfill Reservoir Dams on the Basis of Fuzzy Logic. In IJCCI, 367-373.

Sadegheslam, G., Mikaeil, R., Rooki, R., Ghadernejad, S., \& Ataei, M. (2013): Predicting the production rate of diamond wire saws using multiple nonlinear regression analysis. Geosystem engineering, 16, 4, 275-285. https://doi.or $\mathrm{g} / 10.1080 / 12269328.2013 .856276$.

Sariisik, A., \& Sariisik, G. (2010): Efficiency analysis of armed-chained cutting machines in block production in travertine quarries. Journal of the Southern African Institute of Mining and Metallurgy, 110, 8, 473-480.

Tutmez B., Kahraman S., Gunaydin O. (2007): Multifactorial fuzzy approach to the sawability classification of building stones. Construction and Building Materials, 21, 16721679 .

Tumac, D. (2015): Predicting the performance of large diameter circular saws based on Schmidt hammer and other properties for some Turkish carbonate rocks. International Journal of Rock Mechanics and Mining Sciences, 75, 159168. https://doi.org/10.1016/j.ijrmms.2015.01.015.

Tumac, D. (2016): Artificial neural network application to predict the sawability performance of large diameter circular saws. Measurement, 80, 12-20. https://doi.org/10.1016/j. measurement.2015.11.025.

Tumac, D., \& Shaterpour-Mamaghani, A. (2018): Estimating the sawability of large diameter circular saws based on classification of natural stone types according to the geological origin. International Journal of Rock Mechanics and Mining Sciences, 101, 18-32. https://doi.org/10.1016/j. ijrmms.2017.11.014.

Tumac, D., Avunduk, E., Copur, H., Bilgin, N. and Balci, C. (2013): Estimation of the performance of chain saw machines from shore hardness and the other mechanical properties. In: Feng, Hudson \&Tan. (eds.): Rock Characterisation, Modelling and Engineering Design Methods, 261265. ISBN:978-1-138-00057-5.

Tumac, D. (2014): Predicting the performance of chain saw machines based on Shore scleroscope hardness. Rock mechanics and rock engineering, 47, 2, 703-715.

Wright, D. N., \& Cassapi, V. B. (1985): Factors influencing stone sawability. Industrial Diamond Review, 45, 2, 84-7.

Wei, X., Wang, C. Y., \& Zhou, Z. H. (2003): Study on the fuzzy ranking of granite sawability. Journal of materials processing technology, 139,1,3, 277-280. https://doi. org/10.1016/S0924-0136(03)00235-8.

Yilmazkaya, E. M. R. E., Dagdelenler, G., Ozcelik, Y., \& Sonmez, H. (2018): Prediction of mono-wire cutting machine performance parameters using artificial neural network and regression models. Engineering geology, 239, 96-108. https://doi.org/10.1016/j.enggeo.2018.03.009.

Yurdakul, M., \& Akdas, H. (2012): Prediction of specific cutting energy for large diameter circular saws during natural stone cutting. International Journal of Rock Mechanics and Mining Sciences, 53, 38-44. https://doi.org/10.1016/j. ijrmms.2012.03.008.

\section{SAŽETAK}

\section{Ocjena rezivosti stijena s lančanom sjekačicom primjenom tehnike PROMATHEE}

Jedan od najvažnijih čimbenika u procjeni cijene vađenja građevinskoga kamena jest njegov iznos pridobivanja tijekom strojnoga rezanja. Procjena iznosa proizvodnje takvih strojeva ima vrlo veliku i praktičnu ulogu. Ovdje je načinjena procjena i odabir prikladnoga radilišta unutar kamenoloma radi postizanja najvećega iznosa proizvodnje. Za analizu su odabrani kamenolomi mramora Dehbid i Shayan. Načinjena su terenska ispitivanja, tj. mjerenje operativnih svojstava sjekačice, iznosa pridobivanja te uzorkovanje za laboratorij na sedam smjestišta. Zatim su u laboratoriju za mehaniku stijena izmjerena fizička i mehanička svojstva stijena poput jednoosne kompresijske čvrstoće, brazilske vlačne čvrstoće, abrazije metodom Los Angeles, udjela kvarca, postotka apsorpcije vlage, šupljikavosti, Schmidtove čvrstoće i veličine zrna. Na kraju je ocijenjena rezivost materijala na radilištu kamenoloma uporabom tehnike PROMETHEE, koja predstavlja alat za donošenje odluka na temelju više kriterija koji obuhvaćaju fizička i mehanička svojstva. Rezultati su pokazali kako radilišta označena brojevima 1 i 5, na kamenolomima Dehbid i Shayan, imaju najbolja svojstva postizanja veće-

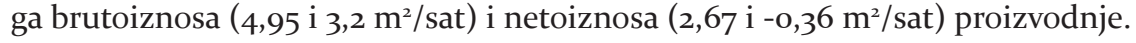

\section{Ključne riječi:}

kamenolom građevinskoga kamena, lančana sjekačica, iznos proizvodnje, PROMETHEE

\section{Author's contribution}

Reza Mikaeil (Associate Professor) performed the design, implementation of the research. Akbar Esmaeilzade (Assistant professor) did analysis of the data collected from the questionnaires. Sara Aghaei (Master degree), Sina Shaffiee Haghshenas (Master degree), Amir Jafarpour (Master degree) completed literature review and participated in all work. Javad Mohammadi (Phd) performed the field work and executed experimental tests. Mohammad Ataei (Full Professor) managed the whole process and supervised it from the beginning to the end. 